\title{
KNJIŽEVNICI I DRUGI PISCI IZ VELEBITSKOG PODGORJA
}

Ante Bežen

Učiteljski fakultet

Sveučilište u Zagrebu

Trg maršala Tita 14

HR 10000 Zagreb

ante.bezen@ufzg.hr
UDK: 821.163.42(497.5 Podgorje)

Pregledni članak

Ur.: 2017-05-04

Velebitsko podgorje, tj. prostor primorske padine Velebita između Sv. Jurja i Zrmanje, zbog demografskih, geografskih, gospodarskih i političkih okolnosti, nije područje intenzivnijeg autohtonog individualnog duhovnog stvaralaštva. O njemu se zato s toga gledišta može govoriti uglavnom kao o prostoru rođenja kulturnih stvaralaca - književnika, publicista i znanstvenika koji su svoj životni put nastavili u razvijenijim sredinama i tamo dali odgovarajući doprinos hrvatskoj kulturi i znanosti. U radu se navode 22 autora iz područja književnosti, publicistike, novinarstva i raznih znanosti koji su rođeni u Velebitskom podgorju. U obliku leksikonskih natuknica izvješćuje se o činjenicama iz njihova života i stvaralaštva koje su zabilježene u relevantnim i autoru ovog teksta dostupnim izvorima.

Ključne riječi: Velebitsko podgorje, književnici, publicisti, novinari, znanstvenici

\section{Uvod}

Pisanje o književnicima i drugim stvaraocima iz Velebitskog podgorja otežava činjenica da nema jedinstvenog stava o međama toga prostora ni $\mathrm{u}$ znanosti ni u narodu. Sigurno je samo da se pod tim nazivom podrazumijeva primorska padina Velebita, ali nije sigurno koja mu je međa na sjeveru a koja na jugu. Izvjesno je tek da se u taj geografski pojam ne može uvrstiti grad Senj, a ni velebitska sela iznad Senja - Krivi južno od Senja, odnosno da taj prostor počinje s područjem sela Sveti Juraj. Ne može se sa sigurnošću govoriti ni o južnoj Put i Veljun Primorski. To znači da je sjeverna međa Velebitskog podgorja međi jer je po nekima ona kod Starigrada Paklenice, a po drugima na rijeci Zrmanji ${ }^{1}$. No,

${ }^{1}$ U Hrvatskoj enciklopediji navodi se: "Velebitsko podgorje, područje u podnožju Velebita, između Senja i rijeke Zrmanje", što nije precizno s obzirom na sjevernu među. 
kako tema ovoga rada zahtijeva jasne međe podgorskoga prostora da se ne bi pogriješilo u zavičajnom svrstavanju ljudi, opredijelio sam se prihvatiti mišljenje da se Velebitsko podgorje prostire od Svetog Jurja na sjeveru do rijeke Zrmanje na jugu. Za to ima geografskih i antropoloških razloga u koje ovdje neću ulaziti. Pripominjem i da je nesigurno i samo ime ovog prostora. Zove li se on Velebitsko podgorje ili samo Podgorje? Na većini zemljopisnih karata piše samo Podgorje, no podgorje je opća imenica kojom se mogu označiti i prostori drugih planina. U Hrvatskoj ima više naselja s tim nazivom (područje Virovitice, Gvozda, Kaptola, Orebića), a susreće se i u Sloveniji i Bosni i Hercegovini. Zato je radi preciznosti nužno u imenu navesti o kojemu se podgorju radi. Stoga se autor rada opredijelio za precizan naziv u ovom članku - Velebitsko podgorje.

To područje prostire se u dvije hrvatske županije - većim sjevernim dijelom kroz Ličko-senjsku, a manjim južnim dijelom kroz Zadarsku županiju. Naselja pripadaju trima nižim administrativnim jedinicama u sastavu županija: Gradu Senju i Općini Karlobag u Ličko-senjskoj te Općini Starigrad - Paklenica u Zadarskoj županiji. Na području Velebitskog podgorja nema jednog kulturnogeografskog ni administrativnog središta prema kome bi bilo usmjereno cijelo to područje. Jedina su veća središta glavna mjesta općina - Karlobag i Starigrad Paklenica, no u njima nema intenzivnijeg vlastitog kulturnog života. U kulturnom je smislu područje Podgorja usmjereno na tri veća grada - Zadar, Gospić i Senj. To objašnjava i činjenicu da se s kulturnog gledišta o tom kraju može govoriti samo kao o prostoru rođenja, a ne i stvaralaštva najvećeg broja onih koji iz njega potječu. Duhovni stvaraoci koji su i stvarali u samom Podgorju su oni koji su se u njemu našli zbog svećeničke, odnosno učiteljske službe koju su tu obnašali. A takva su tek dvojica i po rođenju nisu bili Podgorci. Važno je također navesti da do sada nije bilo sustavnog istraživanja ove teme. Zbog svih navedenih dilema bilo bi dobro da geografska znanost standardizira naziv i međe ovoga područja koje svakako ima svoja posebna geografska i kulturno-antropološka obilježja te time postoje i razlozi da se posebno proučava.

U svrstavanju i obradi književnika i drugih pisaca iz Velebitskog podgorja trebalo je odrediti i kriterije njihova razvrstavanja. Utvrdio sam sljedeće kriterije:

- mjesto i vrijeme rođenja (Podgorci su svi oni koji su rođeni u Podgorju)

- boravak u Podgorju većim dijelom života (u stvaraoce iz Podgorja mogu se ubrojiti i oni koji nisu rođeni u Podgorju, ali su na tom prostoru boravili i stvarali veći dio života)

- stilovi stvaralaštva: u tekst su uključeni ponajprije književnici i publicisti s opširnijim te znanstveni i stručni pisci s ograničenim podatcima (jer se radi o specijaliziranim piscima za koje je potrebno posebno istraživanje) 
- razina doprinosa hrvatskoj kulturi (pisci od nacionalnog značenja, regionalni pisci).

$\mathrm{Na}$ osnovi navedenih kriterija svrstavanja i obrade književnici i drugi pisci obrađeni su kao leksikonske natuknice, kronološki poredani po stoljećima u kojima su rođeni. Natuknice su raspoređene u dvije skupine: KNJIŽEVNICI, JEZIKOSLOVCI, PUBLICISTI, NOVINARI te ZNANSTVENI I STRUČNI PISCI. Pojedine natuknice sastoje se od uobičajenih leksikografskih informacija: prezime i ime, mjesta i nadnevci rođenja i smrti, područja rada i stvaralaštva, životni tijek i opis rada i stvaralaštva sa značajnijim djelima, važnija dostupna literatura. Kao izvor informacija poslužili su objavljeni leksikoni i enciklopedije, drugi dostupni izvori, podatci na internetu (Google) na temelju pretrage imena i prezimena, a iznimno na Wikipediji.

Pregled književnika i drugih pisaca po županijama kojima pripadaju njihova mjesta rođenja odnosno boravka izgleda ovako, slijedom od sjevera prema jugu Velebitskog podgorja:

$\begin{array}{lc}\text { Ličko-senjska županija } & \text { Zadarska županija } \\ \text { - Sveti Juraj } & - \text { Tribanj } \\ \text { Vladimir Jurčenko (boravak) } & \text { Vid Došen } \\ \text { Pavle Rogić } & - \text { Starigrad Paklenica } \\ \text { - Lukovo } & \text { Jure Petričević } \\ \text { Ivan Rogić Nehajev } & \text { Dušan Petričević } \\ \text { - Starigrad kod Senja } & \text { Mira Trošelj } \\ \text { Branko Benzia } & \text { Branko Katalinić } \\ \text { - Stinica } & \text { Zoran Šikić } \\ \text { Stjepan Vukušić } & \text { Seline } \\ \text { - Jablanac } & \text { Vladislav Vežić } \\ \text { Šime Balen } & \text { Podprag } \\ \text { Rudolf Baričević } & \text { Boris Maruna } \\ \text { Mile Butković Podgorac } & \\ \text { Karlobag } & \\ \text { Miroslav Vukelić Mesalov } & \\ \text { Bosiljka Pavić-Fajdić } & \\ \text { Ljudevit Slamnik } & \\ \text { Šime Starčević (boravak) } & \\ \text { Slobodan Martin Šikić } & \\ \text { Milivoj Gabelica } & \end{array}$


U Velebitskom podgorju ima dakle 10 naselja u kojima su rođeni ili su u njima trajno boravili značajniji stvaraoci pisane riječi. Slijede kronološki (po vremenu rođenja) poredani prikazi njihova života i stvaralaštva.

\section{KNJIŽEVNICI, JEZIKOSLOVCI, PUBLICISTI, NOVINARI}

\section{Rođeni u 18. stoljeću}

VID DOŠEN (Tribanj kod Starigrada - Paklenice, 1720. - Dubovik kod Slavonskog Broda, 6. travnja 1776.), književnik i svećenik. Potječe iz bunjevačke obitelji, kakve su, bježeći pred Turcima iz Bosne i Hercegovine, naselile djelomice Velebit i njegovo podgorje. Početno školovanje završio je kod popova glagoljaša u rodnom kraju koji je tada pripadao ninskoj biskupiji te je zaređen 1744. Školovanje je nastavio u Križevcima, Grazu i Zagrebu. God.1754. prelazi iz ninske u zagrebačku biskupiju te je kao kapelan službovao kod grofovske obitelji Pejačević i u Požegi, a kao župnik u selu Duboviku kod Slavenskog Broda, gdje je i umro. U Požegi je predavao moralnu teologiju od 1773. do 1776.

U književnosti se javio kao branitelj vodećeg slavonskog prosvjetitelja u 18. stoljeću Matije Antuna Relkovića i njegova djela Satir iliti divji čoviku kojemu autor kritizira i izvrgava ruglu zaostale običaje i primitivizam puka. Relkovićevo djelo napao je pjesmom rugalicom neki anonimni Tamburaš, a Došen mu je odgovorio spjevom Jeka s planine koja na pisme Satira i Tamburaša slavonskog odjekuje i odgovara (Zagreb, 1767.), u kojemu brani i veliča Satira. Drugo je njegovo djelo Aždaja sedmoglava bojnim kopjem udarena i nagrđena iliti sablast griha na sedam glavni griha razdiljena (Zagreb, 1768.). To je religijskomoralistički spjev, s tematikom preuzetom iz kršćanske teologije (sedmoglava aždaja zapravo je sedam glavnih grijeha) u kojem se grijesi detaljno opisuju na životnim primjerima slavonskoga puka. Spjev se stilom i porukom nastavlja na prethodni, vrlo je žestok u suprotstavljanju grijesima iznoseći i najgrublje primjere iz intimnog života, te daje pouke o tjelesnoj i duhovnoj čistoći. Pisao je ikavskom štokavicom kao i Relković, s parno rimovanim osmercima karakterističnima za narodnu književnost. Zbog izravne slikovitosti njegov se stil ponekad označava "naturalističkim". Oštriji je i nemilosrdniji od Relkovića u slikanju grijeha, no radnja mu je razvučena, a izraz općenito bez veće estetske vrijednosti te u tome zaostaje za Relkovićevim. Njegovi epski spjevovi ocijenjeni su kao "popularno polupjesničko štivo prosvjetiteljskog značenja". Ipak, poslije Relkovića najznačajniji je hrvatski pjesnik prosvjetiteljstva u Slavoniji. 
Literatura: Tomo MATIĆ, Život i rad Vida Došena. Djela Vida Došena, Stari pisci hrvatski. Zagreb, 1969, 34; Rafo BOGIŠIĆ, Vid Došen, Zbornik stihova i proze. PSHK,. str. 18. (s potpunom bibliografijom i literaturom), Zagreb, 1973; Dionizije ŠVAGELJ, (1981). Slyčnoryčni odgovor Vida Došena... Рори Jovanu (Znanstveni skup o Vidu Došenu i Blažu Tadijanoviću, Slavonski Brod, 16. rujna 1978., Rastušje i Glogovica, 17. rujna 1978., Osijek: JAZU, Centar za znanstveni rad, 1981, 43-48; L. P, Došen, Vid, Leksikon hrvatskih pisaca, Zagreb, 2000,186.

ŠIME STARČEVIĆ (Klanac kod Gospića, 18. travnja 1784. - Karlobag, 14. svibnja 1859.), svećenik i jezikoslovac, vjerski pisac, poliglot. Osnovnu i srednju školu pohađao je u Varaždinu, studij filozofije u Grazu i Zagrebu, a teologiju završio u Senju te je tu primio svećenički red 1808. Bio je stric i prvi učitelj Ante Starčevića. U svojoj autobiografiji pisanoj na latinskom (prijevod na hrvatski objavio Fran Binički 1918.) o sebi je napisao da je "...tijela slabašna, srednje snage, zdravlja primjerena tome sastavu. Vješt je u ilirskom i latinskom jeziku, dijelom u njemačkom, a malko i talijanskom i francuskom, može čitati sve slavenske osim sorapskoga (tj. lužičkosrpskoga)". Prvu svećeničku službu kao duhovni pomoćnik a potom kao upravitelj župe imao je u Gospiću (19. ožujka 1809. - 3. listopada 1810.), potom je župniku Ličkom Novom (4. listopada 1910. - 14 svibnja 1812.) i Udbini (15.svibnja 1812. - 19.svibnja 1814.), odakle je premješten u Karlobag i tu ostaje do smrti (20.svibnja 1814. 14. svibnja 1859.) Iz Karlobaga je sudjelovao u pretpreporodnim raspravama o uspostavljanju hrvatskog standardnog jezika te surađivao s tadašnjim zadarskim lingvističkim krugom oko časopisa Zora dalmatinska i Glasnik dalmatinski. Objavljivao je i u časopisima Neven i Danica ilirska. U doba Napoleonovih Ilirskih provincija postavljen za urednika službenog lista Telegraph u Ljubljani, ali tome listu složen samo prvi broj. Predložio je štokavsku ikavicu za hrvatski književni jezik i hrvatsku latinicu bez dijakritičkih znakova za slova č, ć, dž,đ,

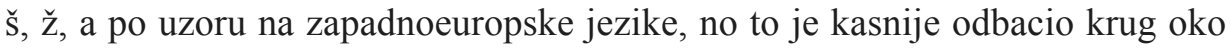
Ljudevita Gaja. Bio je oštar protivnik Gajeve i Karadžićeve jezične reforme te prihvaćanja ijekavskog štokavskog dijalekta za hrvatski književni jezik. Pisac je prve gramatike hrvatskoga jezika na hrvatskom jeziku pod nazivom Nova ricsoslovica iliricska (Trst, 1812.), po čemu je i najznačajniji u hrvatskoj jezičnoj povijesti. U toj je knjizi, pisanoj ličkom štokavskom ikavicom, uveo hrvatske nazive za gramatičke pojmove (većina kasnije nije prihvaćena), a uspostavio je i četveronaglasni novoštokavski sustav koji je kasnije preuzet u hrvatski standardni jezik. Izdao je i Novu ricsoslovicsu iliricsko-francesku (Trst, 1812), što je zapravo prijevod s njemačkog. God. 2009. izdano je njegovo Ricsoslovje (Zagreb). Objavio je i dva religijska djela - Homelie iliti Tumačenje svetog evengjelja za sve nedilje: od Došastja Gospodinova do 
poslidnje nedilje po Duhovih (Zadar, 1850.) i Svagdanja pobožnost i prava izpovid kerstjanska (Zagreb, 1854). Zbog njegova protivljenja ijekavskoj štokavštini kao standardnom jeziku i slovopisu s dijakritičkim znakovima bio je marginaliziran u jezikoslovlju te se, sve do osamostaljenja Hrvatske, spominjao usput i tek u podrubnicama. Budući da je bio pravi borac za posebni identitet hrvatskoga jezika i njegovo razlikovanje od srpskoga, Starčevićev se rad počeo više istraživati u neovisnoj Hrvatskoj, no njegovi se prijedlozi standardizacije hrvatskog jezika više nisu mogli usvojiti. Prvi značajan skup gdje se on posebno ističe organizirao je Institut za hrvatski jezik i jezikoslovlje 2003. U Gospiću pod nazivom Lika i Ličani u hrvatskom jezikoslovlju, drugi je o samom Šimi Starčeviću organizirao Institut za društvena istraživanja Ivo Pilar 2009., a treći Sveučilište u Zadru, Odjel za nastavničke studije u Gospiću, pod nazivom Šime Starčević i hrvatska kultura u 19. stoljeću. Sva tri skupa održana su u Gospiću, a prilozi su objavljeni u dva zbornika. Iako je o Šimi Starčeviću objavljeno dosta istraživanja, njegovo značenje u borbi za identitet hrvatskoga jezika još nije dovoljno vrjednovano u referentnim tekstovima te školskim programima i udžbenicima. Šimi Starčeviću podignut je spomenik u Karlobagu te u Gospiću, zajedno s Antom Starčevićem i Franom Kurelcem.

Literatura: Branka TAFRA, Jezikoslovac Šime Starčević, u: Nova ricsoslovica iliricska,pretisak, Institut za hrvatski jezik i jezikoslovlje, Zagreb, 2002, 127-177; O Šimi Starčeviću opširniji su tekstovi objavljeni u dva zbornika: Lika i Ličani u hrvatskom jezikoslovlju, 2003, Zagreb, Institut za hrvatski jezik i jezikoslovlje te Šime Starčević i hrvatska kultura u XIX. stoljeću, 2014., Zadar - Gospić. Više radova o Šimi Starčeviću objavili su časopisi Senjski zbornik, Zadarska smotra, Rasprave Instituta za hrvatski jezik i jezikoslovlje, Jezik i dr. Iscrpna bibliografija radova o Šimi Starčeviću objavljena je u knjizi Dijane Stolac i Vesne GrahovacPražić, Šime Starčević - od riči do ričoslovja, Državni arhiv u Gospiću, 2015. God. 2017. Institut za hrvatski jezik i jezikoslovlje i Udruga Ličana "Vila Velebita" iz Zagreba izdali su knjigu Lički jezikoslovni trolist - Šime Stračević, Fran Kurelac, Ante Starčević u kojoj je objavljen životopisi bibliografija Šime Starčevića te pretisak njegove Ricsoslovice iliricske.

\section{Rođeni u 19. stoljeću}

VLADISLAV VEŽIĆ (Seline pod Velebitom, 29. travnja 1825.- Varaždin, 16. kolovoza 1894.) pjesnik i prevoditelj. Gimnaziju je završio u Zadru, a studij prava u Zagrebu 1847., radio je uglavnom kao odvjetnik i javni bilježnik, a život je od 1854. do smrti proveo u Varaždinu. Pjesme, domoljubne i ljubavne, objavljivao je u Zori dalmatinskoj, Danici i Viencu. Objavio je romantični kancioner Začinke 1847., a zatim i kraće spjevove Sigetski junak Nikola Zrinski (1866), za 300. obljetnicu bitke pod Sigetom, i Milovanka, pjesan u slavu starca Milovana, prikazana kao ugodni razgovor narodu (1896), posvećena Andriji 
Kačiću Miošiću, glasovitom prosvjetitelju i pjesniku. Za hrvatsku je kulturu znatno važniji kao prevoditelj značajnih djela s francuskog, ruskog, njemačkog i talijanskog jezika (Moliere, Chateaubriand, Ljermontov, Goethe, Dante, Leopardi i dr.). Objavio je i knjigu prijevoda iz romanskih književnosti Vienac francezkoga, talianskoga i španjoljskoga zabavnoga književstva (1852).

Literatura: Vladislav VEŽIĆ, www:enciklopedija.hr, Hrvatska enciklopedija; S. S.: Vežić Vladimir, Leksikon hrvatskih pisaca, Zagreb, 2000; Josip BRATULIĆ - Vladimir LONČAREVIĆ - Božidar PETRAČ, Nikola Šubić Zrinski u hrvatskom stihu, Zagreb Društvo hrvatskih književnika, 2016.; https://library.foi.hr/ knjige

LJUDEVIT SLAMNIK (Karlobag, 1. studenoga 1827. - Split, 31. siječnja 1908.) vjerski pisac i svećenik. Potječe iz činovničke obitelji podrijetlom iz Gorskog kotara. Otac njegov Ferdinand služio je u Karlobagu u državnoj službi te zatim selio s obitelji u Senj i Rijeku. Bogosloviju je završio u Senju, a magisterij teologije u Beču. Radio je kao profesor u Riječkoj gimnaziji, gdje je predavao vjeronauk, hrvatski jezik i geografiju, a zatim postao i ravnateljem. Stekao je veliku ugled kao profesor i branitelj hrvatskih interesa na gimnaziji i u riječkoj sredini. U Hrvatski sabor izabran je kao zastupnik Karlobaga. Objavio je Crkvene molitve i pjesme za gimnazijsku mladež (1858), podlistak u Katoličkom listu Pjevanje i glazba u crkvi, knjižice Život i trpljenje dvadeset i tri japanska mučenika iz reda sv. Franje (1863.) i Svetište u Trsatu (1868.)

Literatura: Irvin LUKEŽIĆ, Ljudevit Slamnik, Rijeka, Sušačka revija, 62/63, Rijeka, 2008.

MIROSLAV VUKELIĆ MESALOV (Karlobag, 1851. (kršten) - Zagreb, 28. kolovoza 1925.), otac hrvatske enigmatike (zagonetke, križaljke u novinama). Osnovnu školu završio je u Senju, gdje je pohađao i gimnaziju, ali, usprkos tome što je bio odličan učenik, nije maturirao. Zaposlio se u carinskoj službi te je radio u carinarnicama u Senju, Kostajnici, Staroj Gradiški, Osijeku i Sisku, gdje je i umirovljen kao šef carine u 42. godini života, vjerojatno zbog naglog slabljenja vida. Napisao je oko 20 tisuća zagonetaka od kojih je većina ostala u rukopisnoj ostavštini. Prvi put se javio u zagrebačkom Dragoljubu 1867., prvu zagonetku objavio u Hrvatskoj lipi 1875., a potom u Hrvatskoj smotri. Oko 1000 zagonetki objavio je u zagrebačkom Ilustrovanom listu u razdoblju od 1914. do 1918. Od 1914. rabi i pseudonim Mesalov. Bio je i među prvim našim sastavljačima križaljki za zabavne rubrike u tisku. Portretirao ga je Izidor Kršnjavi i taj je njegov portret objavljen u Vijencu 1925.

Njegov sin Zvonimir Vukelić (Senj, 1786. - Zagreb,1947.), s pseudonimima, Zyr Xapula i Zyr Vukelić bio je poznati novinar te je uređivao Hrvatsku smotru, satirički list Nos, Hrvatski narod i Polet. Bio je i prvi tajnik 
Hrvatskoga novinarskog društva. Objavljivao je satiričke tekstove i kazališne kritike u Vijencu, Nadi, Prosvjeti i dr., a više satiričnih tekstova izvedeno je u HNK i drugim kazalištima.

Literatura: Slavko PELEH, Miroslav Vukelič-Mesalov, pionir hrvatskog umjetnog zagonetaštva, Senjski zbornik, IV, Senj, 1969/70; Slavko PELEH Još jednom o Mesalovu, Senjski zbornik, IV, Senj, 1969/70; Slavo BANČIĆ, Miroslav Vukelić pionir naše enigmatike, Modra lasta, Zagreb, 1971, 19-20; Stjepan HORVAT, Leksikon zagonetača Jugoslavije, Bjelovar, 1979; Mirko RAGUŽ, Leksikon poznatih Senjana, Senj, 2016.

PAVLE ROGIĆ (Sveti Juraj kraj Senja, 17. siječnja1892. - Zagreb, 24. listopada 1991.), jezikoslovac. U rodnom je mjestu završio osnovnu školu a klasičnu gimnaziju u Senju. Na Filozofskom fakultetu u Zagrebu od 1910. do 1914. studirao je slavistiku i klasičnu filologiju. Kao profesor i direktor gimnazije radio je u više gradova, a neko vrijeme i u Visokoj pedagoškoj školi u Splitu. Od 1948. radi kao znanstveni istraživač u Institutu za jezik i književnost, sve do 1960. godine, kada odlazi u mirovinu. Cijelo to vrijeme radio je kao leksikograf na Rječniku hrvatskoga ili srpskoga jezika JAZU, do njegova završetka, i napisao 1528 njegovih stranica. Sudjelovao je kao pomoćni urednik i urednik u izradi Rječnika hrvatskosrpskog jezika u zajedničkom izdanju Matice hrvatske i Matice srpske te, u ime JAZU, u radu Pravopisne komisije na izradi tzv. novosadskog pravopisa. S Matom Hrastom priredio je treće izdanje Gramatike hrvatskoga ili srpskoga jezika (bez stilistike) Tome Maretića koje je izdano 1963. Znatan broj radova, koje je objavio u časopisima Filologija, Hrvatski dijalektološki zbornik i drugima posvetio je jeziku rodnog kraja: Jedna isprava pisana bosančicom u Senju, Prilog topografiji srednjovjekovnog Senja (1951), Antroponimija sjevernog Velebita (1965), Naseljenost primorske velebitske padine kroz vjekove (1965), Porijeklo stanovnika velebitskih naselja (1969). Osobito su značajni njegovi radovi o antroponimiji sjevernog Podgorja u kojima su zabilježeni podrijetlo i naglasci riječi i koji se ubrajaju među pionirske radove o tim obilježjima zapadnoštokavskog dijalekta. "Njegovi radovi, objavljeni šezdesetih godina u Senjskom zborniku i Hrvatskom dijalektološkom zborniku, postali su za Podgorce izvorom svijesti o sebi, o svome podrijetlu i jeziku" (S. Vukušić). Brojne radove iz morfologije, sintakse, semantike i onomastike objavio je u časopisu Jezik. Umro je od posljedica ozljeda zadobivenih odlaskom u sklonište za vrijeme bombardiranja, tri mjeseca prije navršene stote godine života.

Literatura: Zlatko VINCE, Prof. Pavle Rogić, Jezik, 3, Zagreb, 1992; Stjepan VUKUŠIĆ, Pavle Rogić - znanstvenik iz Velebitskog podgorja, Vila Velebita, 47, Zagreb, 1996. 
Rođeni u 20. stoljeću

ŠIME BALEN (Jablanac kraj Senja, 7. veljače 1912. - Zagreb, 16. ožujka 2004.), novinar, publicist, političar i prevoditelj. Osnovnu školu polazio je u Jablancu i Karlovcu, gimnaziju na Sušaku, a maturirao je u sušačkoj Trgovačkoj akademiji 1930. te se upisao na Ekonomsko-komercijalnu visoku školu u Zagrebu. Od rane mladosti uključio se u politički pokret protiv režima Kraljevine Jugoslavije te je više puta osuđivan kao hrvatski nacionalist. Bio je u zatvorima u Ogulinu, Beogradu, Srijemskoj Mitrovici, Lepoglavi, Mariboru, gdje je prihvatio ideje marksizma i komunizma te je 1935. postao članom Komunističke partije. Radio je kao korektor u novinama i urednik u Hrvatskom dnevniku i Novom listu. Već 1941. odlazi na teritorij pod nadzorom partizana gdje postaje politički komesar u više partizanskih jedinica, a tijekom i poslije rata član je AVNOJ-a i ZAVNOH-a, Privremene narodne skupštine Jugoslavije, državne delegacije u OUN-u i predstavnik za tisak ambasade FNRJ u Washingtonu. God. 1948. isključen je iz KPJ zbog protivljenja progonu Andrije Hebranga te radi kao publicist. God. 1962. postaje direktor Nakladnog zavoda Znanje te je tu i umirovljen 1966. Bio je počasnim predsjednikom Hrvatske demokratske zajednice od 17. lipnja 1989. do 25. veljače 1990 .

Pjesme, novele, putopise, prikaze iz književnosti objavljuje od đačkih dana u velikom broju listova stare (Hrvatski borac, Hrvatski domobran, Naša sloga, Omladina, Obzor, Seljačka misao i dr.) i nove Jugoslavije (Književne novine, Matica, Telegram, Kolo, Naše planine i dr.), a političke priloge u Vjesniku, Matici raznim zbornicima i kalendarima. Pokrenuo je i uređivao središnje novine Vjesnik 1943.- 1945., list Zagrebačka panorama (1960. - 1962.) list Matice iseljenika Matica (1951.- 1959.), iseljeničke kalendare te više samostalnih izdanja različite tematike. Zasebna djela: Istra u narodnooslobodilačkoj borbi (1945), Pavelić (1952), Na zelenim kupolama Zečjaka (1977), Jablanac 1179.1979., u povodu 800. obljetnice (1979), Izgubljeni na Velebitu (1980), Velebit se nadvio nad more -putopisni zapis s planine (1985), Sveta laž (1991), Prva sjećanja: Panos - rat, glad prevrat, seoba (1993). Jedan je od prvih poslijeratnih prevoditelja s engleskog te je preveo na hrvatski značajne američke pisce (neke sa suprevoditeljima): E. Caldwell Duhanski put (1951), Gradić Estherville (1954), Subotnje popodne i druge novele (1960); E. Hemingway Kome zvono zvoni (1952 -1975, 1979); W. Faulkner Svjetlo u augustu (1953., 1964), F. Norris Polip (1955); Crnačka poezija (1956); F. S. Fitzgerald Veliki Gatsby (1959); B. Franklin Autobiografija (1960). Njegove putopise Željko Poljak uvrstio je u Antologiju hrvatske planinarske književnosti (1994), a Dubravko Horvatić 
u antologiju Hrvatski putopis od XVI. stoljeća do danas (2002). Dobio je više priznanja među kojima i Partizansku spomenicu 1941., Plaketu za životno djelo Društva prevoditelja, Nagradu Hrvatskog novinarskog društva Milan Grlović i dvaput Vjesnikovu zlatnu plaketu.

Literatura: Tomo ŽALAC, Balen, Šime, Hrvatski bibliografski leksikon, 1, Zagreb, 1983; Giga GRAČAN, Balen, Šime, Hrvatska književna enciklopedija, 1, Zagreb, 2010.

JURE PETRIČEVIĆ (Starigrad Paklenica, 6. listopada 1912. - Brugg, Švicarska, 24. veljače 1997.), publicist u političkoj emigraciji, poljoprivredni stručnjak. Završio je gimnaziju u Novoj Gradiški (majka mu se preselila u obližnju Vrbovu, a otac je otišao u Ameriku), zatim Poljoprivredno-šumarski fakultet u Zagrebu. Dobio je stipendiju za studij ekonomike agrara na Visokoj tehničkoj školu (ETH) u Zürichu, gdje je doktorirao 1942. Vratio se u Hrvatsku i zaposlio u Ministarstvu poljoprivrede, a 1945. emigrirao u Austriju i potom, zahvaljujući poznanstvima sa studija, uspio prijeći u Švicarsku, gdje se zaposlio u Švicarskom seljačkom savezu i tu radio, kao vrlo cijenjen stručnjak, i nakon umirovljenja 1977. Razvio je aktivnosti među hrvatskim političkim emigrantima i u privatnoj nakladi Adria Verlag, u Knjižnici "Sloboda", objavio 16 izdanja na njemačkom i hrvatskom jeziku o raznim političkim, nacionalnim i gospodarskim temama. Izdanja su bila vrlo cijenjena među Hrvatima u iseljeništvu. Djelovao je kao novinar, publicist i polemičar uvijek radeći za slobodu Hrvatske i hrvatskog naroda. Bio je revan suradnik Hrvatske revije u kojoj je 1956. objavio značajan članak Hrvati i Jugoslavija u kojemu se zalaže za otklon od NDH te kritički govori o politici HSS-a. God. 1960. osnovao je s prijateljima, među kojima su bili i ugledni Hrvati u emigraciji Tihomil Rađa, fra Lucijan Kordić i dr., Hrvatsko društvo u Švicarskoj koje je, među ostalim, izdalo njegovu i Kordićevu knjigu Hrvatski portreti (1973). Bio je i članom švicarske podružnice Europske konferencije za ljudska prava i samoodređenje naroda. Većinu svoje znatne ušteđevine (1,45 milijuna njemačkih maraka) ostavio je, na nagovor prijatelja Lava Znidaršića, Matici hrvatskoj u Zagrebu bez naznake namjene. Uprava Matice odlučila je da tim novcem izgradi novu dvoranu za Matičine aktivnosti, što je i učinjeno pa je dvorana otvorena 2002. u dvorištu Matičine palače u Zagrebu. Ispred dvorane, u zahvalu svom donatoru, Matica je postavila poprsje Jure Petričevića 2010. Neki Petričevićevi prijatelji, koje je predstavljao Marijan Jakopović iz Badena, predlagali su da se novcem osnuje zaklada za stipendiranje studenata agronomije i da se Petričevićevi posmrtni ostatci prenesu u Zagreb (jer u Švicarskoj nema tko brinuti o njegovu grobu), a bili su nezadovoljni i poprsjem, no to je uprava Matice odbacila (tada je 
predsjednik bio Igor Zidić). Nezadovoljstvo su iznijeli javno, a Maticu okrivili za nezahvalnost donatoru. Matica je 2. ožujka 1998. organizirala skup Dr. Jure Petričević, znanstvenik i publicist.

Literatura: Lav ZNIDARČIĆ, Jure Petričević - sjećanje na donatora nove Matičine zgrade, Vijenac, 218, Zagreb, 2002; Damir KOVAČIĆ - Tito ŽIMBREK, Osvrt na agronomske radove dr. sc. Jure Petričevića, Agronomski glasnik, 1-2, Zagreb, 1998; Josip BRATULIĆ, Juri Petričeviću u spomen, Kolo, 3-4, Zagreb, 2010; Z. MITAR, Matica hrvatska i ostavština dr. Jure Petričevića (prema kazivanju Marijana Jakopovića), portal Hrvati u dijaspori.

RUDOLF BARIČEVIĆ (Jablanac kod Senja, 8. travnja 1914. - Zagreb, 10. studenoga 1999.), vojni publicist, pukovnik, doktor pravnih znanosti. U mladosti pisao pjesme, kritike i eseje i objavljivao ih u omladinskim časopisima $L u \check{c}$, Omladina, Mladost te u novinama Novom listu i Obzoru. Bio je u Hrvatskom domobranstvu, vojsci NDH, u 369. pojačanoj pješačkoj pukovniji koja se borila pod Staljingradom. Tada je bio poručnik te je vodio dnevnik pukovnije od 1. ožujka do 18. rujna 1942. i bio "posljednji Hrvat" koji je zrakoplovom izašao iz Staljingrada u noći njegova pada 22./23. siječnja 1943. To je jedini sačuvani dnevnik jedne hrvatske postrojbe iz Drugog svjetskog rata. Pisan je vojnički kratko i sažeto, nadopunjen svjedočenjima te daje vrlo životan prikaz strahota rata, od nedaća uzrokovanih vrlo hladnim vremenom do opisa teških borbi. Pukovnija 369 bila je najveća postrojba Hrvatske legije i jedina strana postrojba koja je s njemačkom vojskom ušla na Staljingrad i došla nadomak Volge. Prema njemačkim izvorima, odlikovala se visokim vojničkim sposobnostima, osobito njezin Topnički sklop, te hrabrošću svojih pripadnika. Od svih izvješća što su ih Ministarstvu oružanih snaga NDH tijekom 1943. podnosili bivši časnici 369. pukovnije, ističe se izvješće poručnika Rudolfa Baričevića koji je u Pukovniji bio od njezina osnivanja u srpnju 1941. do kraja opsade. U knjizi je prikazana sudbina nekoliko stotina preživjelih hrvatskih legionara zarobljenih u Staljingradu 1943. Bogati slikovni materijal čine fotografije pripadnika pukovnije u raznim prigodama. Po povratku u Zagreb R. B. radio je u Ministarstvu vanjskih poslova NDH te nakon njezina sloma emigrirao u Italiju, a potom u Argentinu i SAD. Bio je vrlo aktivan u hrvatskim emigrantskim krugovima i u to vrijeme pisao poeziju. U Hrvatsku se vratio nakon osamostaljenja i objavio knjigu Život $u$ emigraciji (Zagreb, VIGO comerce, 1993).

Literatura: Ana TOMLJENOVIĆ-KOVAČEVIĆ, Relativno vrijeme bivšeg emigranta (intervju s dr. Rudolfom Baričevićem), Vila Velebita, 41, Zagreb, 26. siječnja 1996; Milan POJIĆ, Hrvatska pukovnija 369. na istočnom bojištu, ratni dnevnik 1941 - 1943., Hrvatski državni arhiv, Zagreb, 2007. 
BRANKO BENZIA (Starigrad kod Senja, 1912. - Sv. Juraj kod Senja, 1985.), pjesnik, srednjoškolski profesor. Prezime Benzia potječe s otoka Paga. Osnovnu i srednju školu završio je u Senju, a studij matematike i fizike u Zagrebu 1934. Radio je kao profesor u Travniku, Strumici, Prizrenu, od 1939. u senjskoj gimnaziji, a od 1944. u Beču, gdje se oženio suprugom Hertom koja je dobro govorila hrvatski i gdje je umirovljen 1975. Imao je sklonost prema književnosti, klasičnim jezicima, glagoljaškoj baštini i glazbi. Prevodio je Rilkea, proučavao kulturu Gradišćanskih Hrvata te pisao pjesme nadahnute njihovim životom i običajima. Zbirku pjesama Kraj refula (1994) posvetio je "Hrvaticam u Gradišću", a izdalo ju je Društvo Senjana i prijatelja Senja u Rijeci s popratnom transliteracijom na glagoljicu u albumu pisanim glagoljskim pismom, na temelju kopije izvornog Benziina rukopisa, pisanog glagoljicom i latinicom, u vlasništvu Vatroslava Lopašića, njegova prijatelja sa studija. Glagoljski tekst napisala je Jadranka Ostić iz Pule. Pogovor knjizi napisao je Vatroslav Lopašić s osvrtom na svaku pjesmu. Nakon umirovljenja Benzia se preselio u Sv. Juraj gdje je i pokopan nakon tragične smrti u prometnoj nesreći.

Literatura: Vatroslav LOPAŠIĆ, Bilješke uz pjesme Branka Benzie, www. croatianhistory.net/ etf.lop.htm (priredio Darko Žubrinić) 2004; Mirko RAGUŽ, Leksikon poznatih Senjana, Senj, 2016.

BOSILJKA PAVIĆ-FAJDIĆ (Karlobag, 1918. - Zagreb, 25. studenoga 2000.), kazališna djelatnica, novinarka i prevoditeljica čija je obitelj podrijetlom iz Budaka kod Ličkog Osika. Školovala se u Petrovaradinu, Kraljevu, Senju i Zagrebu. Najprije je radila kao novinarka kulturnog programa Radio Zagreba (1947.-1950.), a potom kao novinarka i prevoditeljica u Hrvatskom narodnom kazalištu u Zagrebu sve do umirovljenja (kazališni arhiv, promidžba). Djelovala je i kao slobodni novinar izvješćujući o HNK u Vjesniku i brojnim drugim glasilima za vrijeme SFR Jugoslavije. Osobito uspješno vodila je intervjue sa svjetski poznatim osobama iz kazališnog i filmskog svijeta, npr.: Laurence Olivier, Giuseppe di Stephano, Gerard Philippe, Vivien Leigh, te velikanima domaće kazališne i operne scene: Bela Krleža, Dragica Martinis, Božena Kraljeva, Tito Strozzi, Mila Dimitrijević, Marijana Radev, Nada Putar-Gold i dr. Prevodila je drame i novele s francuskog jezika. Sudjelovala je u osnivanju i uređenju Ličkih novina 1953. s grupom ličkih intelektualaca u Zagrebu.

Literatura: mjesec.ffzg.hr; katalog.kgz.hr; hbl.Izmk.hr

VLADIMIR JURČENKO (Karlovac, 7. listopada 1930. - Sv. Juraj kod Senja, 21. prosinca 2007.), književnik i učitelj. Djetinjstvo je proveo je u Karlovcu i Virju, učiteljsku školu završio u Križevcima a Pedagošku akademiju u Zagrebu. 
Radio je kao učitelj najprije u Križevcima, Hrženicama kraj Ludbrega i u Puli, a potom došao za učitelja u Podgorje, najprije u Dušikravu i Alan te 1957. u Sveti Juraj, gdje ostaje do kraja života. U Sv. Jurju bio je dugo ravnateljem Osnovne Škole Vjenceslava Novaka, a potom u Senju Osnovne škole Silvija Strahimira Kranjčevića. Bio je strastveni ljubitelj Velebita, njegova biljnog i životinjskog svijeta. S učenicima je u školskoj zadruzi uzgajao domaće životinje, pčele i fazane. Posebna strast bilo mu je proučavanje životinja, slikanje, kiparstvo i književnost. Svoju prvu priču za djecu Čija je djevojčica objavio je u časopisu Radost, a potom sudjelovao i u dječjim časopisima Usponi, Galeb, Istra, listu Vjesnik i dr. Nagrađen je s više odličja i nagrada, među kojima su i Nagrada Grada Rijeke i Nagrada "Ivan Filipović". Napisao je sljedeće knjige pjesama i pripovjedaka: Srce darovano planini (Zagreb, 1977.), Divlje proljeće (Senj,1980.), Dobro jutro vuci i druge priče (Rijeka1983.), Dan između tebe $i$ mene (Senj, 1991.), Svjetlost ognjišta (Senj, 1993), Prisno uz kamen (Senj,1996.). Jedan je od osnivača Senjskog književnog ognjišta, društva za književnost i kulturu. Bio je član Društva hrvatskih književnika. "Vladimir Jurčenko jedini je hrvatski književnik koji je ikada živio i stvarao u Svetom Jurju, a koji je svojim književnim, likovnim i kiparskim radom upisao ovo mjesto u kreativni korpus hrvatske kulture." (Milan Krmpotić)

Literatura: Zlata DEROSSI, Vladimir Jurčenko Divlje proljeće, Senjski zbornik, IX, Senj, 1981/82, 483-488.; Zlata DEROSSI, Vladimir Jurčenko Srce darovano planini, Senjski zbornik, VIII, Senj, 1980, 437-441; N. MIHALJEVIĆ, Jurčenko, Vladimir, Hrvatska književna enciklopedija, 2, Zagreb, 2010; Mirko RAGUŽ, Školstvo senjskog Podgorja, Senj, 2008; Mirko RAGUŽ Leksikon poznatih Senjana, Senj, 2016.

STJEPAN VUKUŠIĆ (Stinica kod Senja, 11. rujna 1931.), književnik, jezikoslovac, sveučilišni profesor. Živi kao umirovljenik u Puli. Osnovnu školu završio je u Jablancu, gimnaziju u Senju, a u Zagrebu Filozofski fakultet (jugoslavistiku), gdje je stekao i doktorat filoloških znanosti. Radio je kao profesor u srednjoj školi u Krku, a od 1965. na Pedagoškoj akademiji, odnosno Pedagoškom fakultetu, i zatim Sveučilištu u Puli gdje je od 1984. redoviti profesor kolegija hrvatskoga jezika. Član je HAZU (Razred za filologiju, Odjel za dijalektologiju), a jedno je vrijeme bio i član uredništva časopisa Jezik. Ubraja se među najznačajnije suvremene hrvatske književnike iz Istre te je u Puli bio u inicijativnom odboru za osnivanje Ogranka Društva hrvatskih književnika 1990. U književnosti se javio 1953. prozom Oproštaj. Njegova su umjetnička inspiracija teme iz senjske okolice, šireg podvelebitskog kraja i Istre, i to iz davnih vremena, razdoblja Austro-Ugarske i Hrvatskoga proljeća. Pisao je pjesme, kratke priče, pripovijetke i romane. Napisao 
je knjigu novela i crtica Burobran (Rijeka, 1970), zatim Da život ne pogaziš (Rijeka, 1973), Svijet pod listincem (Pula 1979), Knjiga od devet naslova (Senj, 1982), Iznad pelina (Senj, 1989), Svjetlost ognjišta (1993), romane Uskraćene blagosti (Pula, 1982) o tradicionalnom hrvatskom intelektualcu, Podgorski vjetar (Zagreb,1996) o životu davnih predaka, Duh u kamenu (Zagreb, 1997) o gradnji amfiteatra u Puli i Admiral (Zagreb, 2008) o prvom hrvatskom admiralu Janku Vukoviću Podkapelskom u vrijeme raspada Austro-Ugarske Monarhije te zbirku pjesama Zemaljskom usprkos (2008). Objavio je više znanstvenih članaka o jezikoslovnim pitanjima te knjigu Naglasak u hrvatskom književnom jeziku (suautori: Ivan Zoričić i Marija Grasselli-Vukušić). Dobio je nagradu Dubravko Horvatić za poeziju 2010. za ciklus pjesama Opijen gorskim šumama.

Literatura: Zlata DEROSSI, Poetski svijet Stjepana Vukušića, Istra, 29, Pula 1991; A. Č., Vukušić, Stjepan, Leksikon hrvatskih pisaca, Zagreb, 2000; Mirko RAGUŽ, Leksikon poznatih Senjana, Senj 2016.

SLOBODAN MARTIN ŠIKIĆ (Karlobag, 1936.), pjesnik modernog izraza, inspiriran, među ostalim, motivima i govorom Karlobaga i podvelebitskog kraja. Živi i djeluje u Karlobagu. Gimnaziju je završio u Senju, a Šumarski fakultet apsolvirao u Zagrebu. Više godina na Radio Zagrebu pripremao je reportaže iz kulturne pučke baštine Like i Velebitskog primorja. Surađivao u listu Vjesnik. Piše aforizme, pjesme, kratke novinske i radio pripovijesti, a napisao je i radiodramu Bakin rođendan. Sudjelovao je u skupovima pjesnika Domaća rič u organizaciji časopisa Zadarska revija u Zadru te su mu pjesme objavljene u zbornicima tih skupova 1997. i 2005., među kojima su i pjesme na baškom (karlobaškom) govoru. Bio je urednik izdanja Kapucinskog samostana u Karlobagu koji mu je objavio zbirke pjesama Bojni pivac (1996), Ništa lakše (1997), Burenje (1998), a objavio je i knjige Pisme od vitra (2000) i Študij za trutove...za mudre, čestite $i$ smjele (2003) u izdanju Ogranka Matice hrvatske u Zadru te Sveto brdo (2010) u izdanju Ogranka Matice hrvatske u Gospiću.

Literatura: Naši pjesnici - Slobodan Martin Šikić, Vila Velebita, 18, Zagreb, 22. veljače 1994; M. PETI, Poezija iz kamena, Vijenac, 447, Zagreb, 2011.

BORIS MARUNA (Podprag, južni Velebit, 13. travnja 1940. - Zagreb, 14. lipnja 2007.), pjesnik, esejist i prevoditelj s engleskog i španjolskog jezika na hrvatski. Osnovnu školu pohađao je u Obrovcu, Zaprešiću i Zagrebu, a gimnaziju završio u Zagrebu. Stvarao je uglavnom u iseljeništvu, kamo je emigrirao 1960. i ostao tridesetak godina (Italija, Argentina, Velika Britanija, SAD i Španjolska). Na sveučilištu Loyola u Los Angelesu diplomirao je i magistrirao angloameričku 
književnost, u Barceloni završio hispanistiku a u Anaheimu računalno programiranje. U Hrvatsku se vratio 1990., no postao je oštar kritičar hadezeovske vlasti priklonivši se političkoj ljevici, razočaran društvenim stanjem u zemlji. Bio je ravnatelj Hrvatske matice iseljenika, a u Matici hrvatskoj urednik Vijenca i Hrvatske revije. Pjesme je počeo objavljivati u omladinskim listovima Polet i Studentski list u Zagrebu. U inozemstvu priključio se 1962. kao stalni suradnik skupini intelektualaca oko Hrvatske revije (izlazila u Buenos Airesu, Parizu, Münchenu i Barceloni) i njezina glavnog urednika Vinka Nikolića. Tada je objavio tri zbirke pjesama: I poslije nas ostaje ljubav (Buenos Aires, 1964), Govorim na sav glas (München -Barcelona, 1972) i Ogorčenje (München- Barcelona, 1985). U domovini objavio je zbirke Ovako (1992), Bilo je lakše voljeti te izdalekapovratničke elegije (1996), izbor iz pjesama Upute za pakleni stroj (1998) i izbor iz ljubavnih pjesama Tako je govorio Katul (2005), sve u Zagrebu. Do smrti bio je veleposlanik Hrvatske u Čileu. Dobio je Goranov vijenac 2000.

Marunina poezija nastala je uglavnom izvan hrvatskog konteksta, pod utjecajem nekih hispanoameričkih i europskih pjesnika, ali s jasnim biljegom izvornosti. Pisana je jednostavnim, svakodnevnim jezikom običnih ljudi. Tematika su većinom životna iskustva, a najčešće ljubav prema domovini, izrečena modernim izrazom, bez klišeja, posve različita od tradicijske romantičarske lirike većine hrvatskih pjesnika emigranata, ali i onih u domovini. Štoviše, ponekad je ciničan prema vlastitoj naciji i prema cijeloj zapadnoj civilizaciji, ogorčen na stvarni život u "obećanoj zemlji" s kojim se sukobljava nacionalna mitologija. U javnosti su upravo zbog te njegove "doslovnosti", otvorenosti, "nesentimentalnog patriotizma" i "demitologizacije književnosti" izazvale posebnu pozornost pjesme Hrvati mi idu na jetra, Bilo je lakše voljeti te iz daljine, Kad dođe pravi čas, Udbaši i dr. U dnevničkoj kronici Otmičari izgubljena sna (1995) govori o poznatoj otmici američkog zrakoplova 10. rujna 1976. koju je sa skupinom istomišljenika izveo Zvonimir Bušić s namjerom da upozori na težak položaj Hrvata u Jugoslaviji. Maruna je bio svjedok i prevoditelj na procesu otmičarima. Pisao je eseje o politici i književnosti i prevodio pjesnike $\mathrm{s}$ engleskog i španjolskog (O. Pazz, Ch. Bukowski, N.Parre i dr.). Zastupljen je pjesmama prevedenima na poljski jezik u antologiji Zywe zradla (1996) i u mađarskoj antologiji A kaosz vigasza (2009).

Literatura: Ante KADIĆ, Ograničenja pjesnika Marune, Hrvatska revija, 1986; Mirjana GREBLO, Misleći drugu Hrvatsku (intervju s Borisom Marunom), Vila Velebita, 41, Zagreb, 26. siječnja 1996; Vlaho BOGIŠIĆ, Maruna, Boris, Leksikon hrvatskih pisaca, Zagreb, 2000; Bruno KRAGIĆ, Maruna, Boris, Hrvatska književna enciklopedija, 3, Zagreb, 2011; predgovori objavljenim knjigama 
IVAN ROGIĆ NEHAJEV (Lukovo kod Senja, 8. svibnja 1943.), književnik i sociolog. Gimnaziju je završio na Sušaku, studij psihologije u Beogradu 1967. te studij sociologije i filozofije 1971. u Zagrebu, gdje je i doktorirao sociologiju 1986. Radio je u Urbanističkom institutu Hrvatske (1989.-1997.) i postao redoviti profesor na Arhitektonskom fakultetu u Zagrebu. Jedan je od utemeljitelja Instituta društvenih znanosti Ivo Pilar u Zagrebu (1991), kojemu je bio i ravnateljem (1995-1998) i tu je radio do mirovine kao znanstveni savjetnik. Bio je i glavni urednik omladinskog lista Tlo. Podjednako je značajan njegov književni i znanstveni rad. U pjesništvu se javio u skupini pisaca oko časopisa Pitanja, koji je izdavao Savez socijalističke omladine, i zbirkom Predgovor (1969.). U njegovoj poeziji susreću se utjecaji hrvatskih pjesnika starijih razdoblja (Kranjčević, Krleža, J. Polić Kamov), no kasnije pretežu postmodernistički hibridi kao što su konkretizam, vizualizam, intertekstualnost, kinetičnost, fragmentarnost i dr. U tom smislu rabi i klasičnu pjesničku formu sonet s tim da osporava njegova tradicijska obilježja . Napisao je zbirke pjesama Odlazak s Patmosa (1971), Marina kruna (1971), Lučke pjesme za pjevanje i recitiranje $i$ druge nerazumljive pjesme (1980), Pjesme o imenima, ženama i drugom (1985), Osnove uranometrije (1994), Pabirci i po koja pjesma (2003). Njegov pjesnički stav ima odjeka i u njegovim izvrsnim kulturološkim i sociološkim esejima: Ogledi i pabirci (1988), Peti stupanj prijenosa (1992), Figure ukroćene sreće (1994), Tko je Zagreb? (1997), Smaragdni brid (1998), Zapisi slobodnog suhozidara (2009).

Literatura: Milorad STOJEVIĆ, Ivan Rogić Nehajev, Dometi, 198; Krešimir BAGIĆ, Brisani prostor, Zagreb, 2002; C. MILANJA, Rogić Nehajev, Ivan, Hrvatska književna enciklopedija, 3, Zagreb, 2011.

MILE BUTKOVIĆ - PODGORAC (Panos kod Jablanca pod Velebitom, 26. travnja 1947.), pjesnik. Osnovnu školu i gimnaziju završio je u Senju, gdje je radio i umirovljen kao knjigovodstveni službenik. Pjesme piše od djetinjstva, ali je prvu pjesmu objavio u 26. godini, a prvu zbirku Utočišta 1987. Surađivao je u Senjskom književnom ognjištu i njegovu časopisu Usponi te u senjskoj Matici hrvatskoj, a kod njih je objavljivao i svoje zbirke. Za njegove je pjesme napisano da se ističu profinjenom osjećajnošću te da je pjesnik ljubavi, zavičaja i tugaljivog doživljavanja svijeta (Ante Dabo). Tiskao je i zbirke i rukoveti pjesama Prstenovi neba (1993), Sloboda krila (1994), Žeđ školjke (1997) i Kap vječnosti (2003).

Literatura: Mirko RAGUŽ, Leksikon poznatih Senjana, Senj 2016. 


\section{ZNANSTVENI I STRUČNI PISCI}

MILIVOJ GABELICA (Karlobag, 17. svibnja 1929. - Zagreb, 15. travnja 2003.), pedagog. Njegov otac Leon, rođen u Podbablju kod Imotskog, bio je financijski kontrolor (umro u 39. godini), a majka Lucija, rođ. Budak, podrijetlom je iz Karlobaga. Osnovnu školu i prvi razred gimnazije završio je u Zagrebu, a u Gospiću učiteljsku školu 1948. tako da se izdržavao kao građevinski i šumski radnik u Velebitu. Radio je u Čazmi i Brestu pod Učkom odakle je, kao uspješan učitelj, premješten u Ministarstvo prosvjete na mjesto referenta za tisak, dječju literaturu i film. Odatle je upućen na studij pedagogije na Filozofskom fakultetu u Zagrebu, a kao student radio je u Školskim novinama poslove novinara, lektora i korektora. Kao apsolvent radio je 1954.-1956. kao učitelj u Vježbaonici zagrebačke Učiteljske škole i tada je proglašen za najboljeg učitelja u Zagrebu. Diplomirao je pedagogiju 1956. Nakon odsluženog vojnog roka radi kraće vrijeme kao učitelj u Osnovnoj školi "Nikola Demonja" u Zagrebu koja je bila vježbaonica Filozofskog fakulteta za studente pedagogije, a odatle prelazi u Republički zavod za osnovno školstvo, gdje postaje prosvjetni savjetnik i republički prosvjetni inspektor te se bavi istraživanjima pravopisne pismenosti, nastave matematike i slobodnih aktivnosti i uređuje i zavodski časopis. God. 1963. primljen je za asistenta na Odsjeku za pedagogiju Filozofskog fakulteta u Zagrebu, katedra za didaktiku i metodike. God. 1970. doktorirao je na istom fakultetu disertacijom Metodika usmenog izlaganja u suvremenoj nastavi. Docentom je postao 1971., a redovitim profesorom 1993. i radio taj posao do umirovljenja predajući metodičke kolegije studentima pedagogije i razredne nastave, a bio je i šef Odsjeka za pedagogiju i voditelj poslijediplomskog studija. Bio je vrlo aktivan u Hrvatskom pedagoško-književnom zboru kojemu je bio potpredsjednik i predsjednik te glavni dugogodišnji urednik časopisa Pedagoški rad (Napredak). Bio je i u uredništvu dječjeg časopisa SMIB i časopisa Roditelji $i$ škola. Nagrađen je godišnjom državnom nagradom "Ivan Filipović" i nagradom za prosvjetne novinare "Tone Peruško". Objavio je niz priloga u časopisu Umjetnost $i$ dijete, Školskim novinama te nekoliko metodičkih priručnika. Glavna njegova djela su Razgovori s roditeljima (1978), Razgovori tobom (1983), Domovina i vjera (1994). U mirovini je pisao haiku poeziju, osobito inspiriran velebitskim primorjem, Likom i Velebitom. Često je boravio u svojoj kući za odmor u Karlobagu sa suprugom Zdenkom, kćeri Majom, zetom Lacijem i unucima Leonom i Lucijanom.

Literatura: Hrvatska enciklopedija; osobna arhiva 
DUŠAN PETRIČEVIĆ (Starigrad - Paklenica, 29. siječnja 1937.), profesor industrijske pedagogije, doktor pedagogije. S roditeljima se 1942. preselio u selo Čačince u Slavoniji, osnovnu školu pohađao u Čačincima i Đurđenovcu, a srednju tehničku školu u Osijeku. Zvanje nastavnika strukovno-tehničke nastave iz strojarstva stekao je na Višoj stručnoj pedagoškoj školi u Rijeci, a na Pedagoškom fakultetu u Rijeci zvanje profesora industrijske pedagogije te magistra i doktora pedagogije. Radio je u srednjim tehničkim školama, u tvorničkim centrima za obrazovanje te kao viši savjetnik u Ministarstvu prosvjete i športa. Kao vanjski suradnik predavao je na Učiteljskom fakultetu u Zagrebu metodike strukovnoteorijske nastave te metodike praktične nastave u programu doškolovanja za nastavnike srednjih strukovnih škola. Na visokoj školi za sigurnost vodio je kolegije radna pedagogija i obrazovanje odraslih na poslijediplomskom studiju. Sudjelovao je u više istraživanja o strukovnom obrazovanju. Objavio je knjige Programiranje obrazovnih sadržaja, Radna pedagogija, Metodika strukovne nastave, Metodika praktične nastave, Obrazovanje odraslih i Kurikulum zanimanja i kvalifikacija, više skripata i monografiju Starigrad-Paklenica. Suautor je knjiga: Opći priručnik na nastavnike srednji šk sola, Školstvo u svijetu, Europska orijentacija hrvatskog školstva i Suvremena pedagogija. Osnivač je i prvi predsjednik Hrvatskog andragoškog društva.

Literatura: https://hr.wikipedia.org. Dušan Petričević (10. 3. 2017.)

MIRJANA TROŠELJ (Starigrad - Paklenica, 22. kolovoza 1949.), profesorica povijesti i povijesti umjetnosti. U Zadru je završila srednju školu, na pedagoškoj akademiji diplomirala likovne umjetnosti 1975., a na filozofskom fakultetu jugoslavistiku i povijest umjetnosti 1980. Radila je kao srednjoškolska profesorica u Novoj Gradiški i Kutini te u Školi za medicinske sestre Mlinarska u Zagrebu. Vrlo je zaslužna za istraživanje kulturne baštine Starigrada - Paklenice i južnog Velebita, a osobito proučava mirila, lokalitete s ikonografskim motivima i ornamentima i narodnu predaju uspoređujući ih sa sličnim nalazima u Bukovici, Ravnim kotarima, Dalmatinskoj zagori te srednjem i sjevernom Velebitu. Pritom surađuje s našim najuglednijim povjesničarima umjetnosti, etnolozima i arheolozima. O tome objavljuje radove u Senjskom zborniku. Sudjeluje u monografiji Mirila - kulturni fenomen u izdanju Slovenske akademije znanosti i umjetnosti, u Studia mithologica slavistica XIV, 2011. dr. Uključena je u projekt Domaća rič Ogranka Matice hrvatske u Zadru te o toponimiji i topografiji južnog Velebita objavljuje u njegovu glasilu Zadarska smotra od 1991. nadalje.

Literatura: www.mirila.org/hr./istraživanja (10. 3. 2017.) 
BRANKO KATALINIĆ (Starigrad - Paklenica, 12. listopada 1952.), inženjer strojarstva i redoviti profesor u trajnom zvanju na Strojarskom fakultetu u Slavonskom Brodu. Diplomirao je magistrirao i doktorirao (1983) na Fakultetu strojarstva i brodogradnje u Zagrebu. Radio u Zavodu za automatiku i mjernu tehniku FSB-a, Tehničkom sveučilištu u Beču. Dobitnik je dva počasna doktorata tehničkih znanosti. Objavio je veći broj znanstvenih radova na više jezika. Član je Odbora za proizvodnju vođenu računalom pri HAZU i osnivač Odbora za tehničke znanosti srednjoeuropskih tehničkih sveučilišta.

Literatura: https://tkojetko.irb.hr (10. 3. 2017.)

ZORAN ŠIKIĆ (Starigrad - Paklenica, 17. veljače 1964.), inženjer šumarstva, sveučilišni nastavnik, visoki državni službenik. Osnovnu školu završio je u Starigradu -Paklenici, srednju šumarsku u Karlovcu 1981., a Šumarski fakultetu Zagrebu 1987. Počinje raditi u Nacionalnom parku Paklenica te 1992. postaje njegov direktor. Sudjeluje kao dragovoljac u Domovinskom ratu i dobiva čin natporučnika. Bio je državni tajnik za zaštitu prirode te pomoćnik ministra u Upravi za zaštitu prirode u Ministarstvu kulture. Na Šumarskom fakultetu u Zagrebu obranio je 2012. disertaciju pod nazivom Tlo $i$ voda u održivom gospodarenju u zaštićenim područjima prirode na primjeru Parka prirode Vransko jezero. Iste godine zapošljava se na Sveučilištu u Zadru u Odjelu za ekologiju, agronomiju i akvakulturu, gdje je izabran u za docenta 2014. Napisao je knjigu Nacionalni park Paklenica (Zagreb,1994.) te više suautorskih tekstova iz područja šumarstva.

Literatura: www.unizd.hr; www.sumari.hr (10.3.2107.)

\section{Zaključak}

Na prostoru Velebitskog podgorja, tj. od Sv. Jurja do Zrmanje, pronašli smo, iz raznih izvora, u 10 mjesta, 22 osobe koje su zabilježene kao autori književnih, publicističkih, novinarskih te znanstvenih ili stručnih djela, a koje su tu rođene ili su boravile veći dio života. Među njima je 15 književnika, publicista i novinara (pretežno književnici: Došen, Vežić, Benzia, Jurčenko, Vukušić, Rogić, S. M. Šikić, Maruna, Butković; pretežno publicisti i novinari: Slamnik, Vukelić, Pavić-Fajdić, J. Petričević, Baričević, Balen), 9 znanstvenika (Starčević, P. Rogić, I. Rogić, Vukušić, Gabelica, D. Petričević, Trošelj, Katalinić, Šikić). Dvojica su podjednako značajni književnici i znanstvenici (Vukušić, I. Rogić). Svi oni su se rodili ili veći dio života obitavali u 10 navedenih podgorskih naselja. U 18. stoljeću rođena su 2 (Došen, Starčević), 
u 19. stoljeću 4 (Vežić, Slamnik, Vukelić, P. Rogić), a u 20. stoljeću 16. Među njima je 20 rođenih na tom prostoru, koji su većinom iz njega otišli i 2 koja nisu rođena u Podgorju, ali su veći dio života u njemu proveli (Starčević, Jurčenko). Po važnosti za nacionalnu kulturu najpoznatiji su svakako jezikoslovac Šime Starčević (prva gramatika hrvatskog jezika na hrvatskom jeziku), pjesnici Boris Maruna i Ivan Rogić, u publicistici Šime Balen, u obrazovanju odraslih Dušan Petričević, a među novinarima, kao začetnik zabavnih priloga u tisku, Miroslav Vukelić Mesalov.

\section{Literatura}

Hrvatski bibliografski leksikon, Zagreb, 1983. - 2013.

Hrvatska enciklopedija, Zagreb, 1999.- 2009.

Hrvatska književna enciklopedija, svesci, Zagreb, 2010 - 2011.

Leksikon hrvatskih pisaca, Zagreb, 2000.

Mirko RAGUŽ, Leksikon poznatih Senjana, Senj, 2016.

\section{LITERARY WRITERS AND OTHER WRITERS FROM VELEBIT PODGORJE}

\section{Summary}

Velebit Podgorje, i.e. the foothill area of the littoral slope of Velebit between Sveti Juraj and the Zrmanja, due to the demographic, geographic, economic and political circumstances, is not a region of intensive indigenous individual spiritual creativity. Therefore from this point of view it is possible to talk about it mainly as the birthplace of cultural creators - literary writers, publicists and scientists who continued their lives in more developed settings and there gave corresponding contributions to Croatia culture and science. 22 authors from the fields of literature, non-fiction, journalism and various sciences who were born in Velebit Podgorje are mentioned in the paper. In the form of lexical entries it reports the facts of their lives and creativity which are recorded in the relevant and available sources available to the author of this text.

Keywords: Velebit Podgorje, literary writers, publicists, journalists, scientists 